\title{
Determinants of Teacher Performance: Exploring the Role of Satisfaction and Motivation as Mediation
}

\author{
Acai Sudirman ${ }^{1 *}$, Sherly², Vivi Candra ${ }^{3}$, Edy Dharma ${ }^{4}$, Darwin Lie 5 iD \\ 1,2,3,4,5 Sekolah Tinggi Ilmu Ekonomi Sultan Agung, Pematangsiantar, Indonesia \\ *Corresponding author: acaivenly@stiesultanagung.ac.id
}

\begin{abstract}
This research aims to determine job satisfaction and motivation as mediating the relationship between teacher certification and principal supervision of teacher performance. The research design used a quantitative approach to causality. To obtain research data using documentation instruments and distributing questionnaires online. The sample used in the study was 215 respondents. The basis for determining the sample is oriented towards a non-probability sampling approach using a purposive sampling formula. To test the mediating effect of satisfaction and the relationship between principal supervision and compensation on teacher performance, the structural equation modeling (SEM) approach with partial least squares analysis is used. Following the research results, Teacher certification has a significant effect on satisfaction and motivation, and teacher certification has no significant effect on teacher performance. The results of subsequent research and the principal's supervision have a significant effect on job satisfaction, motivation, and teacher performance. Furthermore, the results showed that job satisfaction could not mediate the relationship between teacher certification and principal school supervision of teacher performance for the first and second mediation tests. Then, for the third and fourth mediation tests, results were obtained, which stated that motivation could not mediate the relationship between teacher certification and supervision of school principals on teacher performance. Therefore, principal supervision has a significant effect on job satisfaction, motivation, and teacher performance.
\end{abstract}

Keywords: Job Satisfaction, Motivation, Teacher Performance

\begin{tabular}{|c|c|c|}
\hline History: & & Publisher: Undiksha Press \\
\hline Received & : 24 January 2021 & Licensed: This work is licensed under \\
\hline Revised & : 19 February 2021 & a Creative Commons Attribution 3.0 License \\
\hline Accepted & : 26 March 2021 & (c) (†) (?) \\
\hline Published & : 25 April 2021 & EY \\
\hline
\end{tabular}

\section{Introduction}

The satisfaction of each individual varies widely or varies according to the values that exist in him. The higher the assessment of activities following the wishes, the higher the job satisfaction with these activities (Pertiwi et al., 2019). Every teacher has a different perception of job satisfaction. They want to get maximum job satisfaction and according to their wishes (Rafi et al., 2015). Job satisfaction is an essential aspect of human resource management. Job satisfaction is defined as a teacher's emotional state regarding what they have done with what they get (Hidayat et al., 2020). Studies related to teacher job satisfaction are an essential part of advancing education globally (Hariri et al., 2012). When teachers enjoy their work, they do not want to leave school; they are committed to their work and their profession, they are encouraged to do their job very well to achieve school goals (Koedel et al., 2017).

Measuring instruments used in measuring the professional competence of teachers are mastery of the material broadly and deeply, students' understanding, and learning design (Zendrato, 2020). To design professional competencies requires strong encouragement from a 
teacher, which is called motivation. Motivation is everything that must be carried out in a balanced manner by the teachers, in the direction system to encourage teachers to apply the ability to carry out their teaching tasks (Saragih et al., 2019). If the certification undertaken by a teacher has good implications, it will also provide good motivation in carrying out their work (Kanto, 2015). However, it is different from the research results Rivai (2019) confirms that there is no significant effect of obtaining a teacher's certification on motivation. On the other hand, positive motivation will make teachers feel more valued and will automatically improve performance to be more optimal (Hutabarat et al., 2018).

A strong instrument is needed based on the wants and needs needed during the learning process to improve a teacher's performance. One method to improve teacher quality is through teacher certification to determine if a teacher has the appropriate competence to teach (Kusumawardhani, 2017). The development of teacher professionalism through certification is a global concern because teachers have a duty and role in providing information on science and technology and shaping attitudes and souls that can survive in the era of hyper-competition (Pertiwi, 2017). Certification is a competency test process designed to reveal one's competency mastery as a basis for awarding certificates (Handoko et al., 2017). Educators need and must have educational value, competence, certificates, physical and spiritual health, and can realize the goals of national education (Mahtur \& Suwasono, 2018).

The implementation of supervision from the principal aims at the development that is useful from the theoretical aspects by paying attention to the instrumental aspects of leadership in instructional and more tactical and refers to the development tools needed to achieve specific goals (Suchyadi \& Nurjanah, 2018). In general, a teacher prefers to seek advice from colleagues than from a principal. However, effective school principals recognize the importance of supervision that will promote improvements in teacher performance (Tulowitzki, 2019). Since supervision in clinical form is focused on teaching quality, teacher evaluation can be a catalyst in improving teacher teaching and school performance (Veloo et al., 2013). Supervision of the instruction of a principal is one of the functions that are indispensable for the effective operation of the education system in schools (Lucky \& Ogechi, 2019). It needs a teacher's strong motivation to carry out the supervision that is entirely imposed by the principal (Rahmatullah et al., 2019).

Studies related to teacher certification and the supervision of principals have been widely researched in recent decades. Study results Anderson (2019) conveyed that teachers who have been certified and have high morale cannot encourage the improvement and effectiveness of teacher performance. Furthermore, the study results Hazli \& Saputra (2019S) said that there was no significant effect of the supervision given by the principal on teacher performance. Regarding job satisfaction in an educational context, the essence of a teacher's role will be realized if job satisfaction and needs are met (Saiti \& Papadopoulos, 2015) and school performance is mainly dependent on the teaching staff in it (Pang \& Lu, 2018). Research conducted by Arifin (2017) emphasizing that there is a significant effect of job satisfaction on teacher performance. Motivation in a teacher is beneficial for schools because it will create a sense of belonging to the institution (Julyanthry, 2016).

Based on previous research described, there is inconsistency in the results of research that discusses teacher certification and the supervision of principals on teacher performance. Several previous research results separately use job satisfaction and motivation as mediating variables to predict performance. This opens a gap for researchers to investigate the variable teacher certification and supervision of school principals on teacher performance. The author tries to place job satisfaction and motivation as mediating variables in one research model and place teacher certification and principal supervision as predictors of teacher performance. The urgency of the mediating variable to increase the influence of the independent variable 
on the dependent variable and test the significance of the role of the mediating variable. Following the explanation above, the main objective of this study is to determine the effect of teacher certification and principal supervision on job satisfaction and motivation as mediating variables.

\section{Materials and Methods}

The data collected in this study are quantitative. This research was conducted at a private junior high school, Pematangsiantar City, North Sumatra. This research was conducted for 3 months, from May to July 2020. This time was used for data collection, both instrument trial data and research data. The population in this study were all permanent teachers with the status of private teachers in all private junior high schools in Pematangsiantar City and identified by researchers to distribute questionnaires with a total of 320 teachers. The research sample was determined using the purposive sampling technique. The question items set out in the online questionnaire are oriented towards the results of previous research that are relevant to the research topic.

Measurement of the dependent variable, namely teacher performance, is measured using Undang-Undang Nomor 14 Tahun 2005 Tentang Guru Dan Dosen, which consists of 14 indicators. Furthermore, for the first independent variable, teacher certification is measured using previous research Adi et al., (2017), which consists of 10 indicators. Then the second independent variable, namely the supervision of the principal, is measured using previous research Maulid (2017), which consists of 3 indicators. Furthermore, for the first mediating variable, job satisfaction is measured using previous research Iskandar \& Juhana (2014), which consists of 5 indicators. Finally, for the second mediating variable, motivation is measured using previous research Werang et al., (2019), which consists of 3 indicators.

Questionnaires were distributed online using google form media and distributed through WhatsApp and telegram applications to private junior high school teachers in Pematangsiantar City. Based on the recapitulation of respondents' answers who filled out the online questionnaire, it was found that 320 respondents entered the data, but only 215 respondents filled in the data validly.

\section{Results and Discussion Outler Model Measurement}

The results of the data obtained from the research questionnaire were processed using the SmartPLS version 3.2.9 application with management guidelines (Juliandi, 2018). In measuring the outer model, the tests carried out are validity tests and reliability tests. The loading factor and AVE determine convergent validity testing with the condition that the loading factor is above 0.7 and the AVE value is 0.5. (Hair, 2014). According to Ghozali (2014), for the initial stage of the research, a loading value measurement scale of 0.5-0.6 can be used, which will be considered sufficient. According to Hair (2014), model reliability testing is seen from cronbanch's alpha and composite reliability (CR) value, which has a value greater than 0.7. The respective loading factor and AVE values on the indicators of endogenous and exogenous variables and the mediating variable are above 0.7 for the loading factor and above 0.5 for the AVE. Although several question items have a loading factor value between 0.5 to 0.6 , this value is acceptable because this study is an early development model. Furthermore, the value for each reliability above obtained the composite reliability value for all research variables is above 0.7. In addition, for the Cronbach alpha value, the value is above 0.60 for each variable, which indicates that all study variables have a strong reliability value. 


\section{Inner Model Measurement}

Calculation of the inner model is done by bootstrapping research results using SmartPLS 3.2.8. The first is the value of the two related ones, and therefore the R-square of the analysis. Two findings resulting from bootstrapping are available. First, the R-square value is the value that shows the ability of exogenous variables to build endogenous variables. There are three types of R-square value; according to Chin et al. (2008), if the Rsquare value is 0.19 , the relationship between exogenous variables that form endogenous variables is small, if it is 0.33 , the relationship is moderate, and if the value is 0.67 , the relationship is strong. On the other hand, Sarwono (2016) notes that the relationship between endogenous and exogenous is very good if the R-square value is greater than 0.67 .

Table 1. Results of the calculation of the value of R-Square

\begin{tabular}{ccc}
\hline Information & $R$ Square & $R$ Square Adjusted \\
\hline Job satisfaction & 0.284 & 0.277 \\
Motivation & 0.220 & 0.212 \\
Teacher Performance & 0.094 & 0.077 \\
\hline
\end{tabular}

The R-square value of all endogenous variables, namely work satisfaction, motivation, and teacher efficiency, obtained a value below 0.33 from the findings in Table 1 , meaning that the overall capacity of the exogenous variables is small to clarify endogenous variables. In addition, a significance test is used to assess the relationship between exogenous variables and endogenous variables to illustrate the hypothesis test. The important criterion is seen from the p-value. For example, suppose the p-value between the exogenous and endogenous variables is less than 0.05 , with a significance level of $5 \%$. In that case, it means that the exogenous variable has a significant impact on the endogenous variable. On the other hand, if the value is more significant than 0.05 , it means that the exogenous variable has no significant effect on endogenous variables' construction.

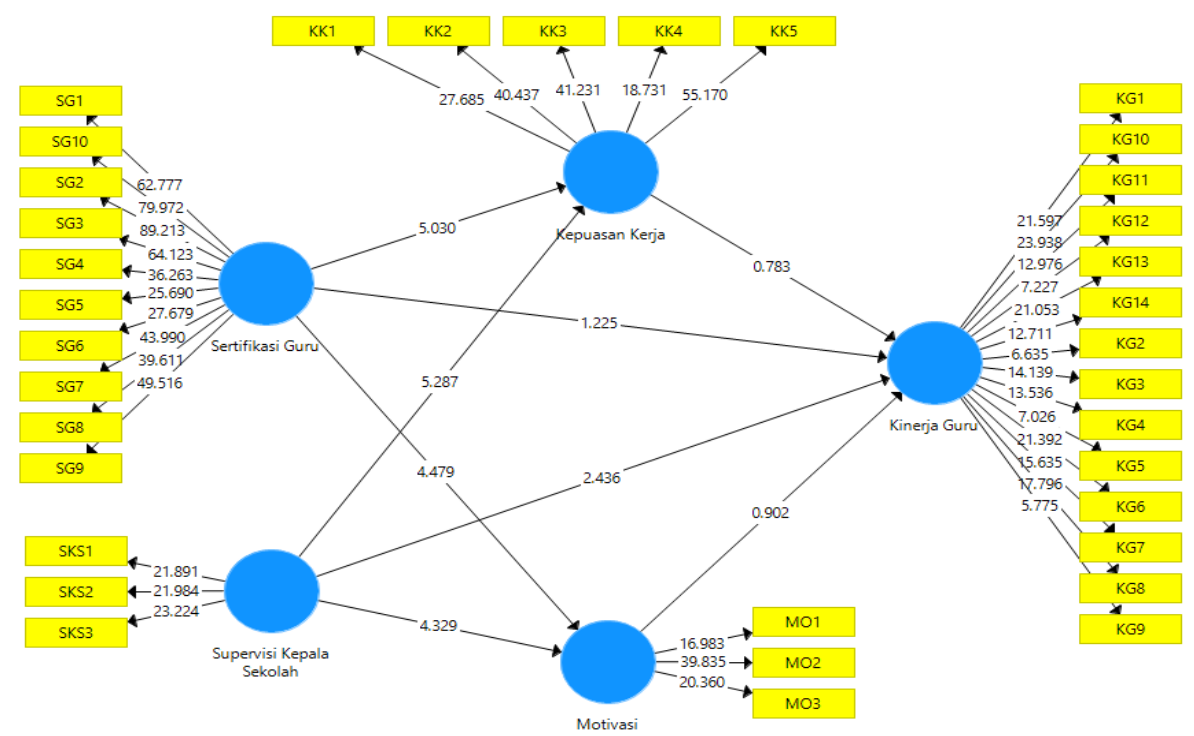

Figure 2. Inner Model Measurement Results 
Table 2. Path Coefficients Test Results

\begin{tabular}{|c|c|c|c|c|}
\hline Path Between Variables & Coefficient & thitung & P-Value & Conclusion \\
\hline $\begin{array}{l}\text { Teacher certification }>>\text { Job } \\
\text { satisfaction }\end{array}$ & 0.300 & 5,030 & 0.000 & Received \\
\hline Teacher certification $>>$ Motivation & 0.254 & 4,479 & 0.000 & Received \\
\hline $\begin{array}{l}\text { Teacher certification }>>\text { Teacher } \\
\text { performance }\end{array}$ & -0.109 & 3,289 & 0.001 & Rejected \\
\hline $\begin{array}{l}\text { Supervision of the principal } \gg>\text { Job } \\
\text { satisfaction }\end{array}$ & 0.351 & 5,287 & 0.000 & Received \\
\hline $\begin{array}{l}\text { Supervision of the principal }>> \\
\text { Motivation }\end{array}$ & 0.318 & 4,239 & 0.000 & Received \\
\hline $\begin{array}{l}\text { Supervision of the principal } \gg \\
\text { Teacher performance }\end{array}$ & 0.171 & 2,436 & 0.015 & Received \\
\hline $\begin{array}{l}\text { Job Satisfaction }>>\text { Teacher } \\
\text { performance }\end{array}$ & 0.114 & 0.783 & 0.434 & Rejected \\
\hline Motivation $>>$ Teacher performance & 0.120 & 0.902 & 0.368 & Rejected \\
\hline
\end{tabular}

The significance test of the direct interaction between exogenous and endogenous variables can be said, based on the processed data provided in table 2 above, that total exogenous variables have a significant effect on endogenous variables. Following the 8 hypotheses developed, only 3 hypotheses were rejected, namely for the direct influence between the teacher certification variable on the teacher performance variable, the results of which were not significant with proving that the p-value was above the 0.05 significance. The direct test results of job satisfaction on teacher performance obtained insignificant results proving that the $\mathrm{p}$-value is above the significance of 0.05 . Furthermore, the direct test results of motivation on teacher performance obtained insignificant results proving that the $p$-value was above the 0.05 significance.

Then for the other 5 hypotheses, it is stated that they are accepted, namely for the effect of the teacher certification variable on the satisfaction and motivation variables significantly. Furthermore, the influence of the principal's supervision variables on job satisfaction, motivation, and teacher performance also has a significant effect. Furthermore, to determine the mediating effect of job satisfaction on the relationship between principal supervision and compensation on teacher performance, a mediation test was carried out using the indirect effect approach, explaining the results as follows: teacher motivation and performance also have a significant effect. Furthermore, to determine the mediating effect of job satisfaction on the relationship between principal supervision and compensation on teacher performance, a mediation test was carried out using the indirect effect approach, explaining the results as follows: teacher motivation and performance also have a significant effect. Furthermore, to determine the mediating effect of job satisfaction on the relationship between principal supervision and compensation on teacher performance, a mediation test was carried out using the indirect effect approach.

Based on the processed data presented in table 3 above, it can be concluded that the job satisfaction variable is not able to mediate the relationship between teacher certification and the supervision of the principal on teacher performance furthermore, whose research results from a state that there is a significant influence between the supervision of the principal on motivation. In comparison, the motivation variable has often seen to be unable to mediate the interaction between teacher certification and teacher success supervision by the school principal. 
Table 3. Mediation Test Results Based on Indirect Effect

\begin{tabular}{lcccc}
\hline Path Between Variables & Coefficient & thitung & P-Value & Conclusion \\
\hline $\begin{array}{l}\text { Teacher certification > > Job } \\
\quad \text { Satisfaction >> Teacher Performance }\end{array}$ & 0.034 & 0750 & 0.454 & Not Mediating \\
$\begin{array}{l}\text { Teacher certification > Motivation } \\
\quad>>\text { Teacher Performance }\end{array}$ & 0.030 & 0.901 & 0.368 & Not Mediating \\
$\begin{array}{l}\text { Principal Supervision > > Job } \\
\quad \text { Satisfaction >> Teacher Performance }\end{array}$ & 0.040 & 0.752 & 0.452 & Not Mediating \\
$\begin{array}{l}\text { Principal Supervision >> Motivation } \\
\quad \text { > Teacher Performance }\end{array}$ & 0.038 & 0826 & 0.409 & Not Mediating \\
\hline
\end{tabular}

\section{Discussion}

The results showed that teacher certification had a significant effect on job satisfaction. The urgency of a certified teacher is the ability to make observations to provide an assessment to students while in a classroom environment (Blazar \& Kraft, 2017). A teacher who has a certification tends to do work that is oriented towards the level of satisfaction received, which means that the better the process of implementing a teacher's certification will impact the level of acceptance of his satisfaction (Milner \& Laughter, 2015). The results of this research are in line with the findings presented by Kanto (2015), Salam \& Heriyanto (2018), Suhada et al. (2017), whose research results state that there is a significant influence between teacher certification on job satisfaction. The results of further research indicate that teacher certification has a significant effect on motivation. The teacher carrying out his duties will be based on the motivation behind him to do work called motivation (Murwati, 2013). This result is reinforced by the findings presented by Kanto (2015), whose research results state that there is a significant influence between teacher certification on motivation. Then for the following research results indicate that teacher certification has no significant effect on teacher performance. Further study results from Anderson (2019) conveyed that teachers who have been certified and have high morale cannot encourage the improvement and effectiveness of teacher performance. The results of this research are in line with the findings presented by Kusumawardhani (2017), whose research results state that there is no significant effect between teacher certification on teacher performance.

The results of further research indicate that the supervision of the principal has a significant effect on job satisfaction. Supervision of the principal in education further seeks to improve the teaching and learning process through the effectiveness of optimal teacher performance (Setiawan et al., 2017). Based on the results of this discussion, it is in line with the research results Firdausi (2018); Husnidar et al. (2020); Suchyadi et al. (2019), whose research results state that there is a significant influence between the supervision of the principal on job satisfaction. The results of further research indicate that the supervision of the principal has a significant effect on motivation. A good principal is a principal who has the characteristics of objective supervision and leadership behavior and can provide equal compensation for teachers to generate motivation to excel among them (Pahlawanti et al., 2020). The results of this discussion are in line with the research results of Hartati \& Purba (2019), Muhajirin et al. (2017), Ujiarto et al. (2017). The results of subsequent research indicate that the supervision of the principal has a significant effect on teacher performance. With the guidance on learning methods and learning evaluation techniques by the principal, it has implications for the desire of teachers to be able to maximize their performance (Auliya 
et al., 2012). Based on the results of this discussion, it conforms with the research results Ramadhan (2017); Rismawan (2015); Sulistianto (2014), whose research results state that there is a significant influence between the supervision of the principal on teacher performance.

The results of further research indicate that job satisfaction has no significant effect on teacher performance. Teachers who have a low level of satisfaction will carry out their duties less optimally, are not serious, and lack enthusiasm at work (Arifin, 2017). The results of this research are in line with the findings presented by Ahmadiansah (2016) and Kanto (2015), whose research results state that there is no significant effect between job satisfaction obtained by a teacher on teacher performance. The results of further research indicate that motivation has no significant effect on teacher performance. The heterogeneous nature of the teaching force indicates that teachers will have different types of motivation profiles, which will result in different variations in performance (Richardson \& Watt, 2010). This was reaffirmed by Sudibjo \& Nasution (2020); even if someone has high motivation, someone with low ability cannot perform well. Vice versa, someone with high ability but low motivation will eventually show a low-performance attitude. The results of this research are in line with the findings presented by Haryanto et al. (2020), whose research results state that there is no significant influence between giving motivation to teacher performance.

In the mediation test results, job satisfaction on the effect of teacher certification on teacher performance is not significant. This condition illustrates that job satisfaction is not able to encourage teacher certification in affecting teacher performance. If the level of satisfaction obtained is low, it will not significantly impact teacher performance even though it is encouraged by teacher certification (Widyaastuti \& Yulianto, 2018). However, if the compensation received from the certification program is balanced with the level of job satisfaction, it can encourage increased performance. In the next mediation test, namely the mediating role of job satisfaction on the effect of principal supervision on teacher performance, the results were not significant. The principal's inability to implement comprehensive supervision has implications for decreasing the level of job satisfaction so that it will also be felt that the teacher's performance is less than optimal. This reflects that the implementation of supervision from school principals should be carried out systematically to encourage teacher satisfaction and performance levels (Wiguna \& Suputra, 2016).

In the next mediation test, namely the role of motivational mediation on the effect of teacher certification on teacher performance, the results were not significant. Professional certificates for teachers who have passed the qualifications coupled with motivational tools in the form of material and non-material turns out to be unable to boost teacher performance. This kind of situation is usually due to a lack of encouragement from the certification program to foster motivation at work so that good motivation will have implications for good performance. Then in the motivational mediation test on the effect of principal supervision on teacher performance, the results were not significant. It can be said that the professional assistance provided by a supervisor to a teacher who has problems in implementing the learning process cannot help the teacher fully realize the weaknesses and shortcomings that exist in him. This situation reflects that the motivation given is still weak because the principal has not been able to generate and develop teacher motivation through supervision (Ndapaloka et al., 2016).

\section{Conclusion}

Based on the results of the discussion of this study, it was stated that teacher certification had a significant effect on satisfaction and motivation and teacher certification had no significant effect on teacher performance. However, subsequent research and the 
principal's supervision have a significant effect on job satisfaction, motivation, and teacher performance. Furthermore, the results showed that job satisfaction could not mediate the relationship between teacher certification and principal school supervision of teacher performance for the first and second mediation tests. Then, for the third and fourth mediation tests, results were obtained, which stated that motivation could not mediate the relationship between teacher certification and supervision of school principals on teacher performance. Therefore, with the results of this mediation test, it can be concluded that job satisfaction and motivation failed to increase the effect of teacher certification and principal school supervision on teacher performance.

\section{References}

Adi, T. W., Prambudiarto, N., \& Hidyantari, E. (2017). Pengaruh Sertifikasi Guru Dan Komitmen Guru Terhadap Kinerja Guru. Jurnal Economics and Sustainable Development, 2(1), 25-34. https://www.ejournal-unipra.com/index.php/ESDUNIPRA/article/view/51.

Ahmadiansah, R. (2016). Pengaruh Motivasi Kerja Dan Kepuasan Kerja Terhadap Kinerja Guru Smk Muhammadiyah Salatiga. Inject: Interdisciplinary Journal of Communication, 1(2), 223-236. https://doi.org/10.18326/inject.v1i2.223-236.

Anderson, K. A. (2019). A National Study of the Differential Impact of Novice Teacher Certification on Teacher Traits and Race-Based Mathematics Achievement. Journal of Teacher Education, 71(2), 247-260. https://doi.org/10.1177/0022487119849564.

Arifin, M. (2017). Pengaruh Kompensasi Dan Kepuasan Kerja Terhadap Kinerja (Studi Terhadap Fakultas Keguruan Dan Ilmu Pendidikan Universitas Muhammadiyah Sumatera Utara). Jurnal EduTech, 3(2), 2442-6024. https://doi.org/10.30596/edutech.v3i2.1255.

Auliya, U. U., Thomas, P., \& Latifah, L. (2012). Pengaruh Supervisi Kepala Sekolah Dan Motivasi Kerja Guru Terhadap Kinerja Guru. Economic Education Analysis Journal, 1(2), 1-9. https://journal.unnes.ac.id/sju/index.php/eeaj/article/download/520/546.

Blazar, D., \& Kraft, M. A. (2017). Teacher and Teaching Effects on Students' Attitudes and Behaviors. Educational Evaluation and Policy Analysis, 39(1), 146-170. https://doi.org/10.3102/0162373716670260.

Firdausi, A. (2018). Pengaruh Supervisi dan Kepercayaan Diri terhadap Kepuasan Kerja Guru SMKN di Jakarta Timur. Jurnal SAP, 2(3), 270-278. https://doi.org/10.30998/sap.v2i3.2453.

Ghozali, I. (2014). Structural Equation Modeling, Metode Alternatif dengan Partial Least Square (PLS). Badan Penerbit Universitas Diponegoro.

Hair, J. F. (2014). Multivariat Data Analysis 7th Edition. Pearson Prentice Hall.

Handoko, T. A., Sumowo, S., \& Rozzaid, Y. (2017). Pengaruh Sertifikasi Dan Motivasi Berprestasi Terhadap Kinerja Guru. Jurnal Penelitian IPTEKS, 2(2), 168-179. http://jurnal.unmuhjember.ac.id/index.php/PENELITIAN_IPTEKS/article/view/1900.

Hariri, H., Monypenny, R., \& Prideaux, M. (2012). Principalship in an Indonesian school context: Can principal decision-making styles significantly predict teacher job satisfaction? School Leadership and Management, 32(5), 453-471. https://doi.org/10.1080/13632434.2012.723617.

Hartati, S. L., \& Purba, S. (2019). The Influences of Principal's Supervision, Teacher's 
Empowerment, Achievement Motivation on Teacher's Organizational Commitment at the Junior High School. International Conference on Research of Educational Administration and Management, 400, 12-16. https://doi.org/10.2991/assehr.k.200130.130.

Haryanto, C. T., Rispantyo, \& Suprihatmi, S. W. (2020). Peran Kepuasan Kerja Dalam Memediasi Pengaruh Kepemimpinan Terhadap Kinerja Pegawai Di Puskesmas Juwangi Kabupaten Boyolali. Jurnal Manajemen Sumberdaya Manusia, 14(2), 1-19. http://ejurnal.unisri.ac.id/index.php/Manajemen/article/view/4020.

Hazli, H., \& Saputra, R. R. (2019). Analisis Pengaruh Supervisi Pengawas Dan Supervisi Kepala Sekolah Terhadap Kinerja Guru Di Madrasah Ibtidaiyah Kecamatan Sukau Lampung Barat. Jurnal Publikasi Pendidikan, 9(1), 62-68. https://doi.org/10.26858/publikan.v9i1.8002.

Hidayat, D., Maitimo, V. V. S., \& Suwu, S. E. (2020). Increasing Teachers' Work Engagement Through Servant Leadership, Organizational Culture, and Job Satisfaction. Jurnal Pendidikan Dan Pengajaran, 53(1), 90. https://doi.org/10.23887/jpp.v53i1.24911.

Husnidar, Afandi, M., \& Darwis, A. (2020). Pengaruh Supervisi Dan Kepemimpinan Kepala Madrasah Terhadap Kepuasan Kerja Tenaga Pendidik Madrasah Tsanawiyah Se Kecamatan Perhentian Raja. Indonesian Journal of Islamic Educational Management, 3(1), 33-43. https://doi.org/10.24014/ijiem.v3i1.8339.

Hutabarat, D. M., Lie, D., Butarbutar, M., \& Sisca, S. (2018). Pengaruh Motivasi Dan Pengembangan Karir Terhadap Kepuasan Kerja Karyawan Di Pt Alamjaya Wirasentosa Depo Pematangsiantar. Sultanist: Jurnal Manajemen Dan Keuangan, 6(1), 1-11. https://doi.org/10.37403/sultanist.v6i1.110.

Iskandar, S., \& Juhana, E. (2014). Pengaruh Kompetensi Dan Lingkungan Kerja Terhadap Kepuasan Kerja Serta Implikasinya Pada Kinerja Guru Di SDN Baros Mandiri 5 Kota Cimahi. Jurnal Ekonomi, Bisnis \& Entrepreneurship, 8(2), 86-98. https://jurnal.stiepas.ac.id/index.php/jebe/article/view/66.

Juliandi, A. (2018). Structural Equation Model Based Partial Least Square (SEM-PLS): Menggunakan SmartPLS. Program Pascasarjana Universitas Batam.

Julyanthry. (2016). Pengaruh Kepemimpinan Dan Budaya Organisasi Terhadap Kompetensi Guru Smp Sultan Agung Pematangsiantar Dengan Motivasi Sebagai Moderating Variabel. Sultanist: Jurnal Manajemen Dan Keuangan, 4(1), 23-28. https://www.sultanist.ac.id/index.php/sultanist/article/download/61/61.

Kanto, K. (2015). Pengaruh Sertifikasi Terhadap Motivasi Kerja, Kepuasan Kerja \& Kinerja Guru BK SMAN. Journal of Educational Science and Technology (EST), 1(2), 61-73. https://doi.org/10.26858/est.v1i2.1514.

Koedel, C., Li, J., Springer, M. G., \& Tan, L. (2017). The Impact of Performance Ratings on Job Satisfaction for Public School Teachers. American Educational Research Journal, 54(2), 241-278. https://doi.org/10.3102/0002831216687531.

Kusumawardhani, P. N. (2017). Does Teacher Certification Program Lead To Better Quality Teachers? Evidence From Indonesia. Education Economics, 25(6), 590-618. https://doi.org/10.1080/09645292.2017.1329405.

Lucky, E. B., \& Ogechi, U. N. (2019). Usefulness Of Principals Instructional Supervision On Teachers Job Performance In Secondary Schools In Rivers State, Nigeria. International Journal of Innovative Education Research, 7(2), 59-65. 
http://seahipaj.org/journals-ci/june-2019/IJIER/full/IJIER-J-7-2019.pdf.

Mahtur, M. R., \& Suwasono, E. (2018). Pengaruh Sertifikasi dan Motivasi Kerja Terhadap Kinerja Guru SD di UPTD Pendidikan Pemuda dan Olahraga Kecamatan Kauman Kabupaten Tulungagung. Jurnal Revitalisasi:Jurnal Ilmu Manajemen, 7(2), 193-198. https://doi.org/10.32503/revitalisasi.v7i2.821.

Maulid, A. (2017). Pengaruh Supervisi Kepala Sekolah Dan Pengembangan Tenaga Pendidik Terhadap Kinerja Guru Madrasah Aliyah Swasta Di Kabupaten Lima Puluh Kota. JMKSP (Jurnal Manajemen, Kepemimpinan, Dan Supervisi Pendidikan), 1(2), 89-98. https://doi.org/10.31851/jmksp.v1i2.1010.

Milner, H. R., \& Laughter, J. C. (2015). But Good Intentions are Not Enough: Preparing Teachers to Center Race and Poverty. Urban Review, 47(2), 341-363. https://doi.org/10.1007/s11256-014-0295-4.

Muhajirin, Prihatin, T., \& Yusuf, A. (2017). Pengaruh Supervisi Akademik dan Partisipasi Guru pada MGMP Melalui Motivasi Kerja Terhadap Profesionalisme Guru SMA / MA. Educational Management, 6(2), 170-177. https://journal.unnes.ac.id/sju/index.php/eduman/article/view/22783.

Murwati, H. (2013). Pengaruh Sertifikasi Profesi Guru Terhadap Motivasi Kerja Dan Kinerja Guru Di Smk Negeri Se-Surakarta. Jurnal Pendidikan Bisnis Dan Ekonomi (BISE), l(1), 12-21. https://digilib.uns.ac.id/dokumen/detail/30578/Pengaruh-sertifikasiprofesi-guru-terhadap-motivasi-kerja-dan-kinerja-guru-di-smk-negeri-se-Surakarta.

Ndapaloka, V., Hardyanto, W., \& Prihatin, T. (2016). Pengaruh Supervisi Akademik Pengawas Dan Kepemimpinan Kepala Sekolah Melalui Motivasi Berprestasi Sebagai Mediasi Terhadap Kinerja Guru SMK Negeri Kabupaten Ende. Educational Management, $\quad 5(1), \quad 42-54$. https://journal.unnes.ac.id/sju/index.php/eduman/article/view/12956.

Pahlawanti, W. D., Harapan, E., \& Wardiah, D. (2020). The Influence of School Principal Supervision and School Committee Participation on the Quality of Junior High School Education. International Journal of Progressive Sciences and Technologies, 23(1), 324-333. https://doi.org/10.52155/ijpsat.v23.1.2260.

Pang, K., \& Lu, C. S. (2018). Organizational Motivation, Employee Job Satisfaction And Organizational Performance: An Empirical Study Of Container Shipping Companies In Taiwan. Maritime Business Review, 3(1), 36-52. https://doi.org/10.1108/MABR03-2018-0007.

Pertiwi, A. S. (2017). Implikasi Kebijakan Sertifikasi Terhadap Profesionalisme Guru Di Kecamatan Rengat Ajeng. Jurnal Mitra Manajemen, 1(2), 164-177. https://doi.org/10.52160/ejmm.v1i2.21.

Pertiwi, Y., Efendi, E., Wijaya, A., \& Simatupang, S. (2019). Pengaruh Komunikasi Interpersonal Dan Kompensasi Terhadap Kepuasan Kerja Pada Pt Perkebunan Nusantara Iii (Persero) Kebun Bangun. SULTANIST: Jurnal Manajemen Dan Keuangan, 7(2), 11-20. https://doi.org/10.37403/sultanist.v7i2.149.

Rafi, M., Lie, D., Butarbutar, M., \& Efendi, E. (2015). Pengaruh Motivasi Dan Kompensasi Terhadap Kepuasan Kerja Karyawan Pada Kantor Pt. Pln (Persero) Area Pematangsiantar. SULTANIST: Jurnal Manajemen Dan Keuangan, 3(2), 33-41. https://doi.org/10.37403/sultanist.v3i2.52.

Rahmatullah, M., Saleh, M., \& Metroyadi. (2019). Contribution of the Principal Supervision 
and Work Motivation on Teacher Performance at Public High School in Barito Kuala District. Journal of K6, Education, and Management, 2(2), 118-125. https://doi.org/10.11594/jk6em.02.02.06.

Ramadhan, A. (2017). Pengaruh Pelaksanaan Supervisi Akademik Pengawas Sekolah Dan Supervisi Kepala Sekolah Terhadap Kinerja Guru SMK Negeri Di Kabupaten Majene. Journal of Educational Science and Technology (EST), 3(2), 136. https://doi.org/10.26858/est.v3i2.3579.

Richardson, P. W., \& Watt, H. M. G. (2010). Current And Future Directions In Teacher Motivation Research. The Decade Ahead: Applications and Contexts of Motivation and Achievement, 16(2010), 139-173. https://doi.org/10.1108/S07497423(2010)000016B008.

Rismawan, E. (2015). Pengaruh Supervisi Kepala Sekolah Dan Motivasi Berprestasi Guru Terhadap Kinerja Mengajar Guru. Jurnal Administrasi Pendidikan, 22(1), 114-132. https://doi.org/10.31227/osf.io/7azuy.

Rivai, F. A. (2019). Pengaruh Program Sertifikasi Guru Terhadap Motivasi dan Kinerja Guru. Islamic Scientific Journal, 2(2), 78-84. https://doi.org/10.51192/almubin.v2i2.61.

Saiti, A., \& Papadopoulos, Y. (2015). School Teachers' Job Satisfaction And Personal Characteristics: A Quantitative Research Study In Greece. International Journal of Educational Management, 29(1), 73-97. https://doi.org/10.1108/IJEM-05-2013-0081.

Salam, A. F., \& Heriyanto, S. (2018). Pengaruh Sertifikasi Guru Dan Pengembangan Karir Terhadap Kepuasan Kerja Guru Akuntansi Sma Di Kota Cilegon. Cendekia, 12(1), 23-32. https://doi.org/10.30957/cendekia.v12i.434.Hasil.

Saragih, M. A., Lie, D., Butarbutar, M., \& Nainggolan, L. E. (2019). Pengaruh Motivasi Dan Kepuasan Kerja Terhadap Disiplin Kerja Pegawai Pada Kantor Pertanahan Kabupaten Simalungun. SULTANIST: Jurnal Manajemen Dan Keuangan, 6(2), 59-69. https://doi.org/10.37403/sultanist.v6i2.128.

Sarwono, J. (2016). Membuat Skripsi, Tesis dan Disertasi dengan Partial Least Square SEM (PLS - SEM). Andi Offset.

Setiawan, A., Hardhienata, S., \& Rubini, B. (2017). Explanatory Sequential Analysis of Organizational Commitment Based on Organizational Culture, Principal Supervision and Job Satisfaction. International Journal of Innovative Research in Science, Engineering and Technology, 6(1), 20242-20245. https://doi.org/10.15680/IJIRSET.2017.0610046.

Suchyadi, Y., Karmila, N., \& Safitri, N. (2019). Kepuasan Kerja Guru Ditinjau Dari Peran Supervisi Kepala Sekolah Dasar Negeri Di Kecamatan Bogor Utara. Jurnal Pendidikan \& Pengajaran Guru Sekolah Dasar, 2(2), 91-94. https://doi.org/10.33751/jppguseda.v2i2.1453.

Suchyadi, Y., \& Nurjanah. (2018). Relationship between Principal Supervision in Increasing the Job Satisfaction of Private Junior High School Teachers in East Bogor District. Journal of Humanities and Social Studies, 2(1), 26-29. https://doi.org/10.33751/jhss.v2i1.818.

Sudibjo, N., \& Nasution, R. A. (2020). Work environment, work motivation and organizational culture in influencing teachers' performance. Jurnal Pendidikan Dan Pengajaran, 53(3), 276. https://doi.org/10.23887/jpp.v53i3.28533. 
Suhada, Mafra, N. U., \& Puspita, S. (2017). Analisis Sertifikasi Dosen Dan Motivasi Kerja Terhadap Kepuasan Kerja Dan Kinerja Dosen Pada Universitas Swasta Di Kota Palembang. Jurnal Media Wahana Ekonomika, 14(2), 1-13. https://doi.org/10.31851/ekonomika.v14i2.1301.

Sulistianto, A. (2014). Pengaruh Supervisi Kepala Sekolah Dan Komunikasi Interpersonal Terhadap Kinerja Guru Sma Negeri 1 Paninggaran Pekalongan. Economic Education Analysis Journal, $3(3)$

502-508. https://journal.unnes.ac.id/sju/index.php/eeaj/article/view/4503.

Tulowitzki, P. (2019). Supporting Instructional Leadership And School Improvement? Reflections On School Supervision From A German Perspective. Journal of Educational Administration, 57(5), 571-581. https://doi.org/10.1108/JEA-03-20190040 .

Ujiarto, T., Rusdarti, Rifai, R. C., \& Raharjo, T. J. (2017). The Journal of Educational Development Effect of the School Principal' s Management, Academic Supervision , Organizational Culture, and Work Motivation to the Teacher' s Professionalism. The Journal of Educational Development, 5(3), 414-424. https://journal.unnes.ac.id/sju/index.php/jed/article/view/18128.

Veloo, A., Komuji, M. M. A., \& Khalid, R. (2013). The Effects of Clinical Supervision on the Teaching Performance of Secondary School Teachers. Procedia - Social and Behavioral Sciences, 93(2002), 35-39. https://doi.org/10.1016/j.sbspro.2013.09.148.

Werang, B. R., Irianto, O., \& Asmaningrum, H. P. (2019). Pengaruh Motivasi dan Semangat Kerja terhadap Kinerja Guru SD di Distrik Mindiptana, Papua. Musamus Journal of Primary Education, 1(2), 93-103. https://doi.org/10.35724/musjpe.v1i2.1467.

Widyaastuti, S., \& Yulianto, A. (2018). Peran Mediasi Motivasi Kerja Pada Pengaruh Sertifikasi Profesi Dan Kepemimpinan Kepala Sekolah Terhadap Kinerja Guru. Economic Education Analysis Journal, 7(1), 15-28. https://journal.unnes.ac.id/sju/index.php/eeaj/article/view/22852.

Wiguna, I. M. A., \& Suputra, I. D. (2016). Pengaruh Tindakan Supervisi, Pengalaman Kerja, Komitmen Organisasi, Dan Komitmen Profesional Terhadap Kepuasan Kerja Auditor. E-Jurnal Akuntansi Universitas Udayana, 16(1), 444-470. https://ocs.unud.ac.id/index.php/Akuntansi/article/view/15079.

Zendrato, W. (2020). Pengaruh Persepsi Dan Kesiapan Atas Program Sertifikasi Terhadap Motif Berprestasi Guru Pada Sma Swasta Kampus Teluk Dalam Kabupaten Nias Selatan. Jurnal Education and Development, 8(1), 250-257. http://journal.ipts.ac.id/index.php/ED/article/view/1544. 